\title{
KERANGKA PENGAMBILAN KEPUTUSAN UNTUK PEMASARAN PRESISI MENGGUNAKAN METODE RFM, ALGORITMA K-MEANS DAN DECISION TREE
}

\author{
Jupriyanto$^{1}$; Siti Nurlela² \\ Program Pascasarjana Magister Ilmu Komputer \\ STMIK Nusa Mandiri Jakarta \\ www.nusamandiri.ac.id \\ 1jupriyanto.kahar@gmail.com; ${ }^{2}$ siti.sie@nusamandiri.ac.id
}

\begin{abstract}
Precision marketing provides the ability for companies to offer products made specifically to customers and provide the ability for companies to attract customers with specially made marketing messages. This paper presents a new decisionmaking framework using data mining techniques. First, this study presents a trend model for accurately predicting monthly supply quantities; second, using the RFM (Recency, Frequency, Monetary) model to choose attributes to group customers into different groups; third, using the $K$ Means Algorithm to create customer clustering based on RFM data of each customer, fourth, using Decision Tree to identify attribute values that are important for distinguishing different customer groups; and finally, from the process of data mining that researchers do create various bidding strategies that target each customer cluster. Sales data from Syifamart in Subang, West Java, were collected and used in a case study to illustrate how to implement the proposed framework. The research shows that the process of data mining from sales transaction history is 351,158 rows, with customer-based aggregation using the RFM method and extracted using the $k$-means clustering algorithm to form 4 (four) optimal clusters. The four (four) clusters are classified using a decision tree algorithm so Syifamart can find out which potential customers and potential customers. For the availability of stock supply, management predicts the need for product inventory using a trend method where the stock in the following month is predicted by using the sales history in the previous month.
\end{abstract}

Intisari- Pemasaran presisi memberikan kemampuan pada perusahaan untuk menawarkan produk-produk yang dibuat secara khusus kepada pelanggan dan memberikan kemampuan kepada perusahaan untuk menarik minat pelanggan dengan pesan-pesan pemasaran yang dibuat secara khusus. Penelitian ini menyajikan kerangka kerja pengambilan keputusan baru menggunakan teknik data mining. Pertama, penelitian ini menyajikan model tren untuk memprediksi secara akurat kuantitas pasokan bulanan; kedua, menggunakan model RFM (Recency,Frequency, Monetary) untuk memilih atribut untuk mengelompokkan pelanggan ke dalam kelompok sesuai history transaksi belanjanya; ketiga, menggunakan Algoritma $K$ Means untuk membuat clustering pelanggan berdasarkan data RFM masing-masing pelanggan, keempat, menggunakan Decision Tree untuk mengidentifikasi nilai atribut penting untuk membedakan kelompok pelanggan yang berbeda; dan akhirnya, dari proses data mining yang peneliti lakukan menciptakan berbagai strategi penawaran yang menargetkan setiap cluster pelanggan. Data penjualan dari Syifamart di Subang Jawa Barat, dikumpulkan dan digunakan dalam studi kasus untuk menggambarkan bagaimana mengimplementasikan kerangka yang diusulkan. Dari penelitian yang telah dilakukan menunjukan bahwa proses data mining dari history transaksi penjualan 351,158 rows, dengan agregasi berdasarkan pelanggan menggunakan metode RFM dan diekstraksi dengan menggunakan algoritma clustering $k$-means membentuk 4 (empat) cluster optimal. Keempat (empat) cluster tersebut diklasifikasikan dengan menggunakan algoritma decision tree sehingga Syifamart dapat mengetahui mana pelanggan potensial dan mana pelanggan yang tidak potensial. Untuk ketersediaan pasokan stok, manajemen memprediksi kebutuhan persediaan produk dengan menggunakan metode tren dimana stok di bulan selanjutnya di prediksi dengan menggunkana history penjualan di bulan sebelumnya.

Kata Kunci: Pemasaran Presisi, Metode Tren, RFM, K-Means, Decision Tree.

\section{PENDAHULUAN}

Dalam menjalankan roda bisnis, perusahaan membutuhkan strategi pemasaran yang cocok dan efektif dengan bisnis yang sedang mereka jalankan. Hal itu bertujuan untuk menarik pelanggan lebih banyak lagi serta meningkatkan penjualan 
sehingga dapat mendatangkan keuntungan dan juga kesuksesan.Laju percepatan globalisasi ekonomi dan meningkatnya persaingan pasar, tekanan ekonomi dan persaingan usaha telah menyebabkan perusahaan menghadapi masalah memilih kebijakan pengambilan keputusan strategis yang tepat untuk menjual produk yang tepat kepada pelanggan yang tepat pada waktu yang tepat, sehingga perusahaan dapat meningkatkan laba mereka. Baru-baru ini di kenal bahwa pemasaran presisi telah menjadi sarana untuk menghasilkan keuntungan lebih dan menjadi semakin penting karena pelanggan menjadi lebih tahu tentang produk dan hak mereka sebagai pelanggan. Ketersediaan data pelanggan dan catatan transaksi memberikan pemahaman yang lebih baik tentang perilaku dan preferensi konsumsi pelanggan.

Usaha retail, sejumlah biaya dihabiskan untuk menarik pelanggan baru, akan tetapi seiring waktu pelanggan tersebut dapat menghentikan pembelian mereka karena berbagai alasan (Wardani et al., 2018).

Syifamart merupakan sebuah usaha yang selalu meningkatkan kualitasnya baik secara internal maupun eksternal, namun tinggat pemasaran dan penjualan pada syifamart masih sangat rendah.

Model RFM merupakan model yang membedakan pelanggan penting dari data yang besar oleh tiga variabel yaitu recency, frequency dan monetary (Hardiani, Hartanto, \& Mada, 2017). A decision tree is an efficient data mining algorithm with a strong explanatory capability (You et al., 2015)

Penelitian ini bertujuan untuk membuat kerangka kerja pemasaran presisi dengan cara melakukan pengelompokan dan clustering pelanggan menggunakan metode Recency Frequency and Monetary (RFM) dan Algoritma Kmeans serta menggunakan metode prediksi tren sehingga dapat meprediksi kebutuhan persediaan produk yang akan dipasarkan sesuai dengan kebutuhan pelanggan.

\section{BAHAN DAN METODE}

\section{A. Datasets}

Syifamart adalah salah satu Unit Bisnis yang mendukung program dan kegiatan di Yayasan AsSyifa Al-Khoeriyyah. Saat ini Syifamart memiliki sistem yang terintegrasi dengan Smartcard untuk metode pembayarannya. Lokasi Syifamart berada di sekitar kompleks lembaga pendidikan As-Syifa, dengan harapan semua kebutuhan terpenuhi di Syifamart mulai dari makanan ringan sehari-hari, kebutuhan sekolah, kebutuhan kantor hingga kebutuhan rumah tangga bulanan, tidak perlu keluar dari komplek untuk memenuhi kebutuhan internal lembaga.

Penelitian ini menggunakan data yang diambil dari sistem penjualan Syifamart selama 6 bulan, periode Juli 2018 hingga Desember 2018. Dataset untuk 6 bulan adalah 351.158 berdasarkan transaksi penjualan yang ada. Dataset sampel penjualan dapat dilihat pada Tabel 1.

Tabel 1. Dataset Penjualan

\begin{tabular}{|c|c|c|c|c|c|}
\hline $\begin{array}{l}\text { NO } \\
\text { TRANS }\end{array}$ & $\begin{array}{l}\text { NAMA } \\
\text { PRODUK }\end{array}$ & QTY & $\begin{array}{l}\text { TGL } \\
\text { BUKTI }\end{array}$ & HARGA & PLG \\
\hline $\begin{array}{l}\text { J-2018- } \\
220429\end{array}$ & $\begin{array}{l}\text { slay olay } \\
\text { blubbery }\end{array}$ & 20 & $7 / 1 / 2018$ & 1,000 & 2017300006 \\
\hline $\begin{array}{l}J-2018- \\
221862\end{array}$ & $\begin{array}{l}\text { keripik } \\
\text { pusaka } \\
3000\end{array}$ & 1 & $7 / 6 / 2018$ & 3,000 & 2017300010 \\
\hline $\begin{array}{l}\text { J-2018- } \\
221862\end{array}$ & $\begin{array}{l}\text { Twistko } \\
\text { jagung } \\
\text { bakar } \\
80 \mathrm{gr} \\
\end{array}$ & 1 & $7 / 6 / 2018$ & 6,000 & 2017300010 \\
\hline $\begin{array}{l}J-2018- \\
220400\end{array}$ & $\begin{array}{l}\text { rinso } \\
\text { molto } \\
900 \mathrm{~g}\end{array}$ & 1 & $7 / 1 / 2018$ & 19,000 & 2017300022 \\
\hline $\begin{array}{l}J-2018- \\
220400\end{array}$ & $\begin{array}{l}\text { molto } \\
\text { pink all } \\
\text { in one } \\
\text { pouch } \\
300 \mathrm{ml} \\
\end{array}$ & 1 & $7 / 1 / 2018$ & 9,500 & 2017300022 \\
\hline $\begin{array}{l}J-2018- \\
220402\end{array}$ & $\begin{array}{l}\text { sedaap } \\
\text { minyak } \\
\text { greng } \\
\text { 1liter }\end{array}$ & 1 & $7 / 1 / 2018$ & 13,500 & 2017300046 \\
\hline $\begin{array}{l}J-2018- \\
220402\end{array}$ & $\begin{array}{l}\text { Kecap } \\
\text { Bango } 60 \\
\mathrm{ml}\end{array}$ & 1 & $7 / 1 / 2018$ & 3,000 & 2017300046 \\
\hline $\begin{array}{l}J-2018- \\
220402\end{array}$ & $\begin{array}{l}\text { Goodday } \\
\text { Mocacino }\end{array}$ & 2 & $7 / 1 / 2018$ & 1,250 & 2017300046 \\
\hline $\begin{array}{l}\text { J-2018- } \\
220404\end{array}$ & $\begin{array}{l}\text { Frestea } \\
\text { Melati } \\
\text { cup }\end{array}$ & 1 & $7 / 1 / 2018$ & 2,000 & 2017300061 \\
\hline $\begin{array}{l}\text { J-2018- } \\
220406\end{array}$ & $\begin{array}{l}\text { teh } \\
\text { javana } \\
350 \mathrm{ml}\end{array}$ & 7 & $7 / 1 / 2018$ & 3,000 & 2017300068 \\
\hline $\begin{array}{l}J-2018- \\
220410\end{array}$ & $\begin{array}{l}\text { Batre } \\
\text { Abc Kecil }\end{array}$ & 4 & $7 / 1 / 2018$ & 2,500 & UMUM \\
\hline $\begin{array}{l}\text { J-2018- } \\
220412\end{array}$ & $\begin{array}{l}\text { axo } \\
600 \mathrm{ml}\end{array}$ & 1 & $7 / 1 / 2018$ & 2,500 & UMUM \\
\hline
\end{tabular}

Sumber: (Jupriyanto. \& Nurlela, 2019)

\section{B. Metode}

Menurut (widiarina, 2013) Data mining mengusulkan proses standar data mining yang disebut dengan Cross-Industry Standard Process for Data Mining (CRISP-DM).

(Amborwati Armadyah, 2014) menyebutkan bahwa Algoritma data mining yang sering digunakan untuk segmentasi adalah K-Means Clustering dan atributatribut yang digunakan untuk proses mining pada segmentasi konsumen adalah data konsumen, produk, demografi, perilaku konsumen, transaksi, RFMDC, menurut (Tsiptsis K \& A., 2009) K-means menggunakan 
ukuran Euclidean distance dan secara iteratif menentukan tiap record dari cluster asal. RFM (Rerency, Frequency Monetery), dan LTV (Life Time Value). Dan penting untuk menggabungkan algoritma clustering dengan beberapa algoritma data mining lainnya seperti Classification, Association, dan CPV matriks untuk mendapatkan nilai potensial dari tiap cluster.

Pada penelitian ini menyajikan model tren untuk memprediksi kuantitas pasokan bulanan, dan menggunakan gabungan metode RFM, Clustering K-Means dan Klasifikasi Decision Tree untuk profiling pelanggan. Metode penelitan sesuai Gambar 1 di bawah ini :

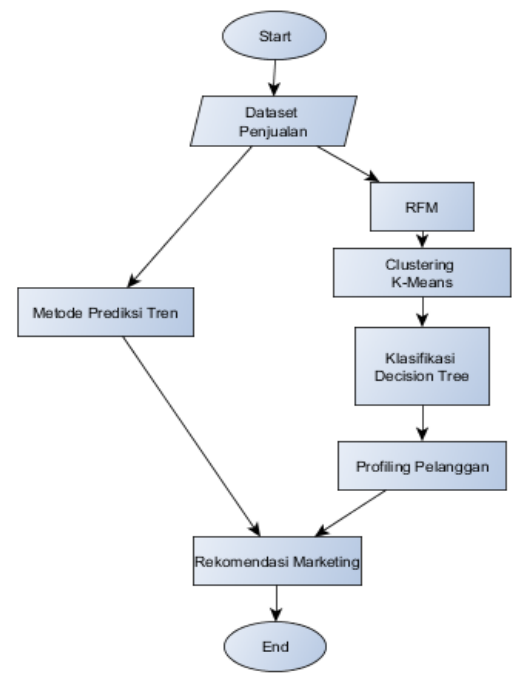

Sumber: (Jupriyanto. \& Nurlela, 2019)

Gambar 1. Metode Penelitian

\section{HASIL DAN PEMBAHASAN}

Penelitian ini menyajikan kerangka kerja pengambilan keputusan baru menggunakan teknik data mining. Pertama, menyajikan model tren untuk memprediksi secara akurat kuantitas pasokan bulanan; kedua, menggunakan model RFM (Recency,Frequency, Monetary), model ini untuk memilih atribut yang akan mengelompokkan pelanggan ke dalam kelompoknya sesuai history transaksi belanjanya; ketiga, menggunakan Algoritma K-Means untuk membuat clustering pelanggan berdasarkan data RFM masing-masing pelanggan, keempat, menggunakan Decision Tree untuk mengidentifikasi nilai atribut penting untuk membedakan kelompok pelanggan yang berbeda; dan akhirnya, dari proses data mining yang peneliti lakukan menciptakan berbagai strategi penawaran yang menargetkan setiap cluster pelanggan.

\section{A. Model Tren}

Model tren ditunjukkan oleh perubahan nilai rata-rata penjualan produk "keripik pusaka 3000" selama perioe 1 July 2018 sampai dengan 31 Desember 2018. Berikut tren penjulan penjulannya selama 6 bulan :

Tabel 2. Tren 6 bulan menjual produk "keripik pusaka 3000"

\begin{tabular}{lr}
\hline Period & Jumlah trx \\
\hline $2018-07$ & 1,773 \\
\hline $2018-08$ & 3,231 \\
\hline $2018-09$ & 3,483 \\
\hline $2018-10$ & 1,749 \\
\hline $2018-11$ & 1,597 \\
\hline $2018-12$ & 1,239 \\
\hline Sumber: (Jupriyanto. \& Nurlela, 2019) &
\end{tabular}

Dari tabel di atas akan dibuat deskripsi data ke dalam bentuk poligon agar dapat memudahkan menganalisis data. Berikut ini adalah poligon data dari data hasil penjualan produk "keripik pusaka 3000" :

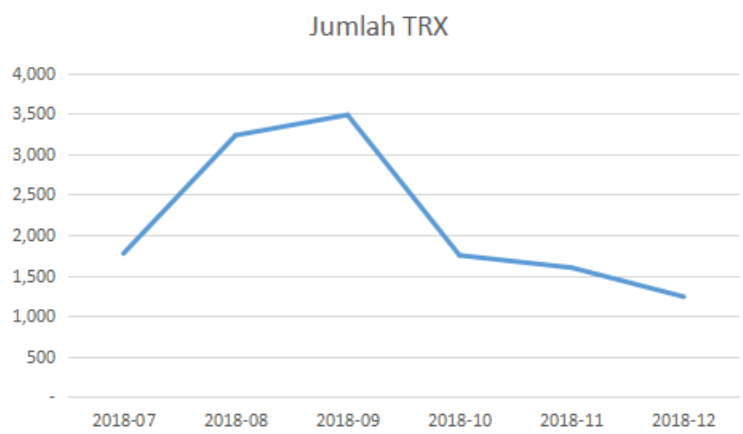

Sumber: (Jupriyanto. \& Nurlela, 2019)

Gambar 2. Grafik polygon Tren 6 bulan menjual produk " keripik pusaka 3000"

Dari grafik poligon di atas, dapat dilihat bahwa setiap bulan penjualan produk "keripik pusaka 3000" fluktuasi dalam hal jumlah transaksi, puncak dari transaksi terbanyak adalah pada bulan September 2018.

\section{B. Model RFM (Recency,Frequency, Monetary)}

Untuk mengklasifikasikan pelanggan, penelitian ini berfokus pada pelanggan yang sebelumnya telah belanja produk. Pra-proses data sebelum membangun model pengambilan keputusan adalah menggunakan metode RFM:

1. Membuang Data Transaksi yang bukan dari member, penelitian ini fokus ke transaksi yang di lakukan oleh member yang memiliki Smartcard RFID.

2. Menentukan produk yang akan di lakukan penelitian, untuk mengakomodir aspek pemasaran presisi dari sisi ketersediaan produk bisa di teliti juga, penelitian ini akan fokus meneliti produk "keripik pusaka 3000" dengan 
total transaksi pembelian oleh member sejumlah 6.744 transaksi dan total nominal transaksi sejumlah Rp 22,424,400.

3. Selanjutnya, kami memilih atribut yang akan digunakan dalam prosedur data mining dari penelitian ini, yaitu atribut RFM (recency, frequency, monetary), sehingga diperoleh data sesuai table 3 berikut ini :

Tabel 3. Data Atribut RFM

\begin{tabular}{rrrrr}
\hline \multirow{2}{*}{ No } & \multirow{2}{*}{ Pelanggan } & \multicolumn{3}{c}{ RFM } \\
\cline { 3 - 5 } & & R (Hari ) & F( Kali ) & M ( Rp) \\
\hline 1 & 2017300006 & 42 & 14 & 42,000 \\
\hline 2 & 2017300008 & 31 & 18 & 60,000 \\
\hline 3 & 2017300010 & 13 & 20 & 60,000 \\
\hline 4 & 2017300018 & 13 & 46 & 138,000 \\
\hline 5 & 2017300022 & 53 & 10 & 33,000 \\
\hline 6 & 2017300027 & 13 & 10 & 30,000 \\
\hline 7 & 2017300029 & 17 & 33 & 99,000 \\
\hline 8 & 2017300036 & 11 & 32 & 96,000 \\
\hline 9 & 2017300043 & 28 & 26 & 93,000 \\
\hline 10 & 2017300045 & 11 & 34 & 105,000 \\
\hline 11 & 2017300046 & 125 & 3 & 12,000 \\
\hline 12 & 2017300061 & 11 & 30 & 93,000 \\
\hline 13 & 2017300068 & 49 & 26 & 81,000 \\
\hline 14 & 2017300074 & 27 & 1 & 3,000 \\
\hline 15 & 2017300075 & 103 & 20 & 60,000 \\
\hline Sunyyy
\end{tabular}

Sumber: (Jupriyanto. \& Nurlela, 2019)

4. Menentukan kriteria pembobotan berdasarkan variabel RFM. Pembobotan dibagi menjadi 5 skala / skor seperti yang tercantum pada Tabel 4.

Tabel 4. Skala RFM

\begin{tabular}{rrrrrrr}
\hline \multirow{2}{*}{ Score } & \multicolumn{2}{c}{ R (hari) } & \multicolumn{2}{c}{$\mathrm{F}$ (kali ) } & \multicolumn{2}{c}{ M (hari) } \\
\cline { 2 - 7 } & Min & Max & Min & Max & Min & Max \\
\hline 5 & 0 & 52 & 48 & 1000 & 146,568 & $10,000,000$ \\
\hline 4 & 53 & 105 & 36 & 47 & 109,926 & 146,567 \\
\hline 3 & 106 & 158 & 24 & 35 & 73,284 & 109,925 \\
\hline 2 & 159 & 211 & 12 & 23 & 36,642 & 73,283 \\
\hline 1 & 212 & 1000 & 0 & 11 & 0 & 36,641 \\
\hline
\end{tabular}

Sumber: (Jupriyanto. \& Nurlela, 2019)

5. Setelah menentukan skala RFM, selanjutya melakukan Skoring Pelanggan berdasar RFM dengan cara melakukan transformasi data RFM menjadi seperti table 5 di bawah ini :

Tabel 5. Skoring Pelanggan

\begin{tabular}{|ccccc}
\hline \multirow{2}{*}{ No } & \multirow{2}{*}{ Pelanggan } & \multicolumn{3}{c}{ RFM } \\
\cline { 3 - 5 } & & $\mathbf{R}$ & $\mathbf{F}$ & $\mathbf{M}$ \\
\hline 1 & 2017300006 & 5 & 2 & 2 \\
\hline 2 & 2017300008 & 5 & 2 & 2 \\
\hline 3 & 2017300010 & 5 & 2 & 2 \\
\hline 4 & 2017300018 & 5 & 4 & 4 \\
\hline
\end{tabular}

\begin{tabular}{ccccc}
\hline \multirow{2}{*}{ No } & \multirow{2}{*}{ Pelanggan } & \multicolumn{3}{l}{ RFM } \\
\cline { 3 - 5 } & & $\mathbf{R}$ & $\mathbf{F}$ & $\mathbf{M}$ \\
\hline 5 & 2017300022 & 4 & 1 & 1 \\
\hline 6 & 2017300027 & 5 & 1 & 1 \\
\hline 7 & 2017300029 & 5 & 3 & 3 \\
\hline 8 & 2017300036 & 5 & 3 & 3 \\
\hline 9 & 2017300043 & 5 & 3 & 3 \\
\hline 10 & 2017300045 & 5 & 3 & 3 \\
\hline 11 & 2017300046 & 3 & 1 & 1 \\
\hline 12 & 2017300061 & 5 & 3 & 3 \\
\hline 13 & 2017300068 & 5 & 3 & 3 \\
\hline 14 & 2017300074 & 5 & 1 & 1 \\
\hline 15 & 2017300075 & 4 & 2 & 2 \\
\hline Sumber: (Jupriyanto. \& Nurlela, 2019) & &
\end{tabular}

\section{Algoritma K-Means}

Setelah semua data transaksi diubah menjadi angka, maka data tersebut dapat dikelompokkan dengan menggunakan algoritma Kmeans. Untuk dapat mengelompokkan data ke dalam beberapa kluster diperlukan beberapa langkah sebagai berikut:

a. Menentukan jumlah kluster yang diinginkan. Dalam penelitian ini data yang ada akan dikelompokkan menjadi empat kelompok.

b. Menentukan titik pusat awal dari setiap cluster. Dalam penelitian ini titik pusat awal ditentukan secara acak dan diperoleh titik pusat setiap cluster yang dapat dilihat pada tabel 6

Tabel 6. Titik Pusat Cluster

\begin{tabular}{ccccc}
\hline Pusat Cluster & Pelanggan & R & F & M \\
\hline CLUSTER 1 (C1) & 2017300029 & 5 & 3 & 3 \\
\hline CLUSTER 2 (C2) & 2017300312 & 5 & 5 & 5 \\
\hline CLUSTER 3 (C3) & 2017300375 & 5 & 2 & 2 \\
\hline CLUSTER 4 (C4) & 2017300668 & 4 & 2 & 2 \\
\hline Sumber: (Jupriyanto. \& Nurlela, 2019) & & &
\end{tabular}

c. Tempatkan setiap data dalam kluster. Dalam penelitian ini, metode k-means digunakan untuk mengalokasikan setiap data ke dalam sebuah cluster yang paling dekat dengan titik pusat setiap cluster. Untuk mengetahui cluster mana yang paling dekat dengan data, diperlukan untuk menghitung jarak setiap data dengan titik pusat masing-masing cluster. Misalnya, menghitung jarak dari data transaksi pelanggan $=2017300027$ ke pusat klaster pertama:

$D(i, j)=\sqrt{(x 1 i-x 1 j)^{2}+(x 2 i-x 2 j)^{2}+. .+(x k i-x k j)^{2}} . .(1)$

diperoleh jarak ke masing-masing cluster adalah :
1. $\mathrm{D}(\mathrm{C} 1)=2.828427125$
2. $\mathrm{D}(\mathrm{C} 2)=5.656854249$ 


\section{3. $\mathrm{D}(\mathrm{C} 3)=1.414213562$ 4. $\mathrm{D}(\mathrm{C} 4)=1.732050808$}

Dari perhitungan di atas, jarak terdekat peanggan 2017300027 adalah ke cluster 3 (1.414213562), sehingga member 2017300027 di masukan ke cluster 3. Hasil perhitungan lengkap dengan pusat cluster inisial bisa di lihat di table 7 .

Tabel 7. Jarak ke masing-masing cluster

\begin{tabular}{|c|c|c|c|c|c|}
\hline \multirow{2}{*}{ PELANGGAN } & \multicolumn{4}{|c|}{ JARAK KE } & \multirow{2}{*}{$\begin{array}{c}\text { DEKAT } \\
\text { KE }\end{array}$} \\
\hline & $\mathrm{C} 1$ & $\mathrm{C} 2$ & C3 & $\mathrm{C} 4$ & \\
\hline 2017300006 & 1.41 & 4.24 & - & 1.00 & $\mathrm{C} 3$ \\
\hline 2017300008 & 1.41 & 4.24 & - & 1.00 & $\mathrm{C} 3$ \\
\hline 2017300010 & 1.41 & 4.24 & - & 1.00 & $\mathrm{C} 3$ \\
\hline 2017300018 & 1.41 & 1.41 & 2.83 & 3.00 & $\mathrm{C} 1$ \\
\hline 2017300022 & 3.00 & 5.74 & 1.73 & 1.41 & $\mathrm{C} 4$ \\
\hline 2017300027 & 2.83 & 5.66 & 1.41 & 1.73 & $\mathrm{C} 3$ \\
\hline 2017300029 & - & 2.83 & 1.41 & 1.73 & $\mathrm{C} 1$ \\
\hline 2017300036 & - & 2.83 & 1.41 & 1.73 & $\mathrm{C} 1$ \\
\hline 2017300043 & - & 2.83 & 1.41 & 1.73 & $\mathrm{C} 1$ \\
\hline 2017300045 & - & 2.83 & 1.41 & 1.73 & $\mathrm{C} 1$ \\
\hline 2017300046 & 3.46 & 6.00 & 2.45 & 1.73 & $\mathrm{C} 4$ \\
\hline 2017300061 & - & 2.83 & 1.41 & 1.73 & $\mathrm{C} 1$ \\
\hline 2017300068 & - & 2.83 & 1.41 & 1.73 & C1 \\
\hline
\end{tabular}

Sumber: (Jupriyanto. \& Nurlela, 2019)

d. Setelah semua data ditempatkan ke dalam cluster terdekat, kemudian kalkulasi ulang pusat klaster baru berdasarkan rata-rata anggota dalam klaster.

e. Setelah mendapatkan titik pusat baru dari masing-masing cluster, kembali dari langkah c hingga titik pusat setiap cluster tidak berubah lagi dan tidak ada data yang bergerak dari satu cluster ke cluster lainnya.

Dari hasil pengolahan data yang dilakukan berdasarkan dataset transaksi pelanggan menggunakan K-Means melalui 4 iterasi, maka terbentuklah cluster seperti yang ditunjukkan pada Gambar 3 yang menunjukkan bahwa hasil clustering diperoleh 65 anggota cluster 1, 21 anggota cluster 2, 294 anggota cluster 3 , dan 232 anggota cluster 4 .

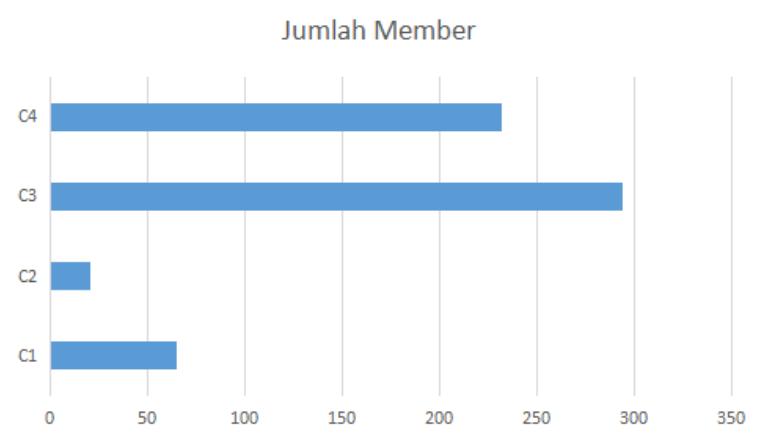

Sumber: (Jupriyanto. \& Nurlela, 2019) Gambar 3. Grafik Sebaran Cluster
Dari hasil pengelompokan, perlu untuk menguji validitas cluster dengan menghitung Indeks Davies Bouldin untuk menentukan apakah jumlah cluster yang terbentuk optimal atau tidak.

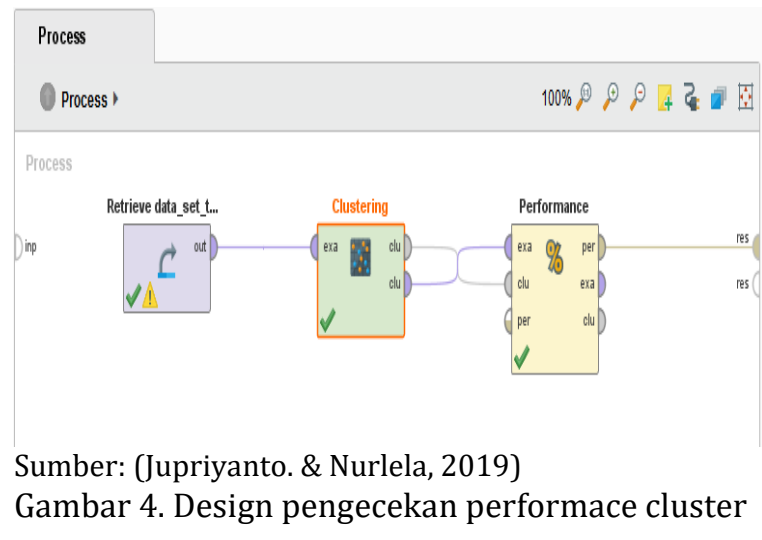

Cluster adalah konvergen jika tidak ada perubahan atau pergerakan anggota dari satu cluster ke cluster lainnya. . Selain itu, gugus konvergen juga ditandai dengan tidak ada perubahan dalam nilai-nilai indeks DB. Dari lima skenario pengujian yang telah dilakukan, peringkat akan dibuat berdasarkan nilai indeks-DB terbaik. Tingkat optimal dari suatu cluster dapat diukur dengan Nilai Indeks DB. Davies dan Bouldien menyebutkan bahwa jumlah cluster terbaik adalah yang memiliki indeks terkecil di antara kelompok lain.

Tabel 8. Nilai Indeks DB

\begin{tabular}{cc}
\hline Jumlah Cluster & DB-index \\
\hline 2 & -0.626 \\
\hline 3 & -0.673 \\
\hline 4 & -0.518 \\
\hline 5 & -0.552 \\
\hline
\end{tabular}

Sumber: (Jupriyanto. \& Nurlela, 2019)

Hasil penelitian menunjukkan bahwa jumlah cluster 4 memiliki Indeks Davies Bouldien (DI) terkecil di antara cluster lain dari 0,518 yang tercantum pada Tabel 2

\section{Decision Tree}

Setelah menemukan segmentasi pelanggan, berikutnya akan dianalisis pada setiap segmen untuk menentukan karakteristik pelanggan menggunakan Algoritma Decision Tree. Tujuan klasifikasi adalah untuk mengetahui informasi penting yang terdapat dalam data transaksi pelanggan yang didasarkan pada Keterkinian, Frekuensi, Moneter (RFM) dan Cluster. Tabel 9 menunjukkan jumlah lengkap data transaksi Pelanggan. Dalam proses ini, di teliti sebanyak 612 dataset yang terdiri dari 4 kluster. 
Tabel 9. Member Cluster

\begin{tabular}{ccc}
\hline No & Cluster & Jumlah Member \\
\hline 1 & Cluster 1 & 65 \\
\hline 2 & Cluster 2 & 21 \\
\hline 3 & Cluster 3 & 294 \\
\hline 4 & Cluster 4 & 232 \\
\hline
\end{tabular}

Sumber: (Jupriyanto. \& Nurlela, 2019)

Pembentukan model klasifikasi dilakukan dengan mengimplementasikan data ke Rapidminer Studio 9.1 dengan dataset adalah hasil Clsutering menggunakan K-Means yang berjumlah 612 data menghasilkan pohon model dan aturan penentuan karakteristik pelanggan.

Hasil dari model klasifikasi dapat dilihat sebagai pohon pada Gambar 4 dan model klasifikasi ini melibatkan 4 atribut yaitu Keterkinian, Frekuensi, Moneter (RFM) dan Cluster.

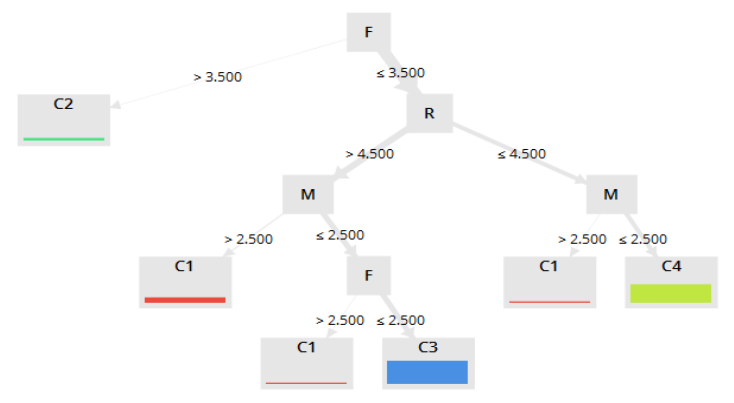

Sumber: (Jupriyanto. \& Nurlela, 2019)

Gambar 5. Model Decision Tree untuk Menentukan Karakteristik Pelanggan

Hasil prediksi dari penetapan parameter karakteristik pelanggan pada 612 data menghasilkan prediksi sebesar 98,86\%.

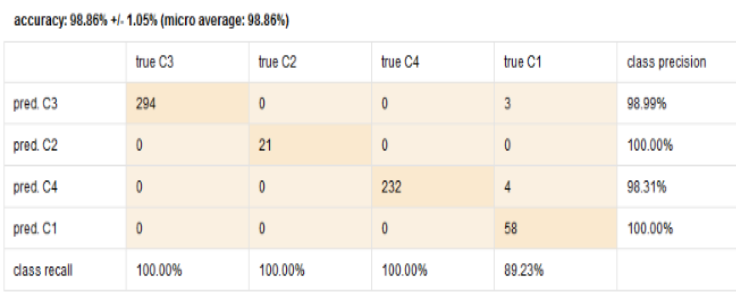

Sumber: (Jupriyanto. \& Nurlela, 2019)

Gambar 6. Deskripsi dari Model Decision Tree untuk Menentukan Karakteristik Pelanggan

Profil pelanggan dilakukan dengan menggunakan aturan yang dihasilkan dari proses sebelumnya. Karakteristik pelanggan yang digunakan dalam profil pelanggan adalah karakteristik menurut (Maryani \& Riana, 2017) Tabel 10 adalah karakteristik pelanggan yang dihasilkan dalam penelitian ini.
Tabel 10. Karakteristik Pelanggan

\begin{tabular}{|c|c|c|}
\hline $\begin{array}{l}\text { Type } \\
\text { Pelanggan }\end{array}$ & Cluster & Karakteristik Pelanggan \\
\hline $\begin{array}{l}\text { Pelanggan } \\
\text { Berulang }\end{array}$ & 1 & $\begin{array}{l}\text { Pelanggan dalam Cluster } 1 \\
\text { disebut sebagai pelanggan } \\
\text { tetap, yaitu pelanggan yang } \\
\text { telah melakukan pembelian } \\
\text { suatu produk } 2 \text { kali atau } \\
\text { lebih. }\end{array}$ \\
\hline Klien & 2 & $\begin{array}{l}\text { Pelanggan dalam Cluster } 2 \\
\text { disebut sebagai tipe } \\
\text { pelanggan Klien. Mereka } \\
\text { membeli secara teratur, dan } \\
\text { hubungan dengan pelanggan } \\
\text { jenis ini telah kuat dan akan } \\
\text { bertahan lama yang } \\
\text { membuat mereka tidak } \\
\text { terpengaruh oleh tarikan } \\
\text { pesaing dari produk lain. }\end{array}$ \\
\hline Penganjur & 3 & $\begin{array}{l}\text { Pelanggan dalam Cluster } 3 \\
\text { melakukan pembelian rutin, } \\
\text { dengan nominal yg terbatas. } \\
\text { Ini sangat menguntungkan } \\
\text { bagi perusahaan. Pelanggan } \\
\text { jenis ini juga dapat } \\
\text { digunakan sebagai pasar } \\
\text { perusahaan karena jenis } \\
\text { pelanggan ini melakukan } \\
\text { pemasaran untuk } \\
\text { perusahaan dengan } \\
\text { mendorong teman-teman } \\
\text { mereka untuk membeli } \\
\text { barang / jasa di perusahaan. }\end{array}$ \\
\hline $\begin{array}{l}\text { Pelanggan } \\
\text { Pertama } \\
\text { Kali }\end{array}$ & 4 & $\begin{array}{l}\text { Pelanggan dalam Cluster } 4 \\
\text { memiliki karakteristik } \\
\text { tingkat intensitas rendah. } \\
\text { Mereka adalah pelanggan } \\
\text { baru yang tingkat } \\
\text { kedatangannya sangat } \\
\text { rendah. Pelanggan jenis ini } \\
\text { adalah pelanggan yang } \\
\text { membeli untuk pertama } \\
\text { kalinya, mereka masih } \\
\text { pelanggan baru. }\end{array}$ \\
\hline
\end{tabular}

Sumber: (Maryani \& Riana, 2017)

\section{E. Implementasi System}

Untuk kebutuhan manajemen dan tim marketing Syifamart, dibawah ini implementasi dari kerangka kerja Pemasaran Presisi yang telah dibuat.

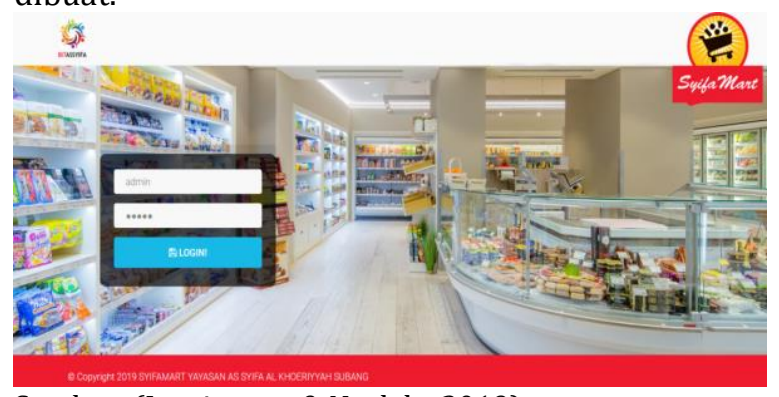

Sumber: (Jupriyanto. \& Nurlela, 2019)

Gambar 6. Halaman login Implementasi System 
Tim marketing atau manajement Syifamart di berikan akses username dan password, sehingga bisa masuk ke system yang peneliti buat.

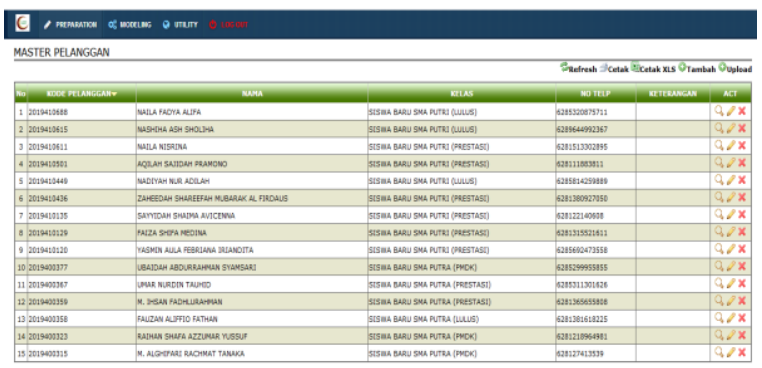

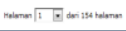

Sumber: Jupriyanto dan Nurlela (2019)

Gambar 7. Data pelanggan untuk preparation penelitian

Dalam penelitian ini data pelanggan / member akan di gunakan sebagai subyek. Berdasarkan data pembelian yang ada di Syifamart, pelanggan / member akan ketahuan di cluster mana posisnya berada.

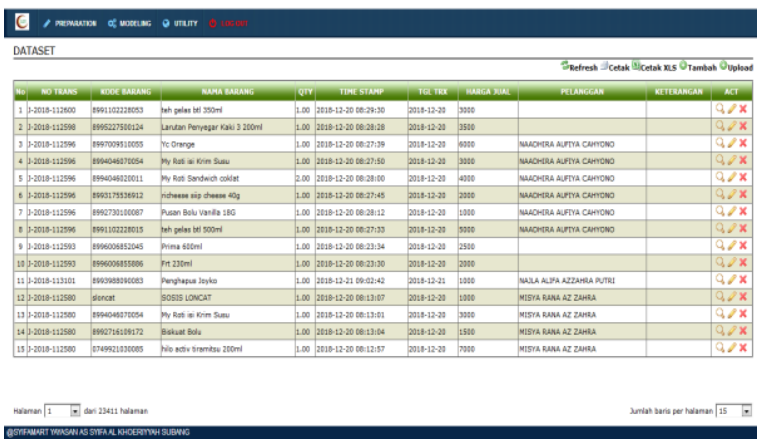

Sumber: (Jupriyanto. \& Nurlela, 2019)

Gambar 8. Dataset penjualan Syifamart

Dataset penjualan Syifamart yang di gunakan dalam penelitian ini adalah data penjualan periode July 2018 sampai dengan Desember 2018, dengan fokus penelitian adalah penjualan yang menggunakan smart card. Penjualan pelanggan umum di keluarkan dari dataset untuk kevalidan dalam membuat clustering pelanggan.

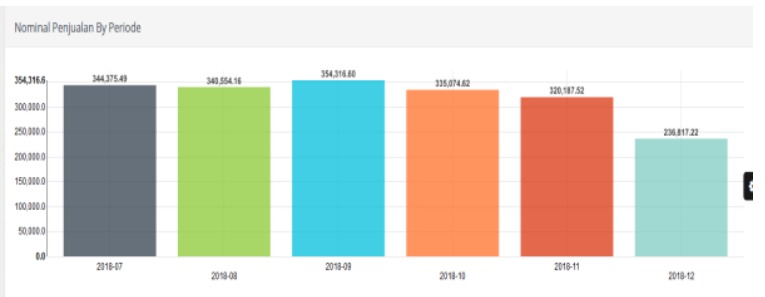

Sumber: (Jupriyanto. \& Nurlela, 2019)

Gambar 9. Penjualan by periode bulan
System / tool yang di buat, menampilkan historikal penjualan setiap bulannya untuk memudahkan tim Marekting atau manajemen dalam menentukan ketersediaan stok produk yang ada di Syifamart.

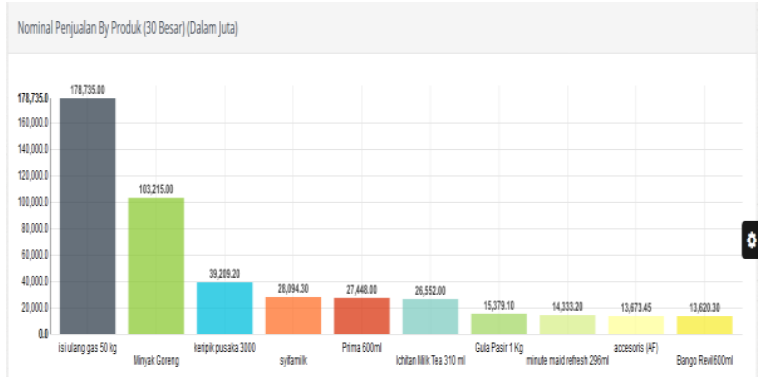

Sumber: (Jupriyanto. \& Nurlela, 2019)

Gambar 10. Penjualan by produk

System / tool yang di buat juga menampilkan historikal penjualan setiap produk yang ada, untuk memudahkan tim Marekting atau manajement dalam menentukan stok produk yang mana yang harus di prioritaskan ada di Syifamart.

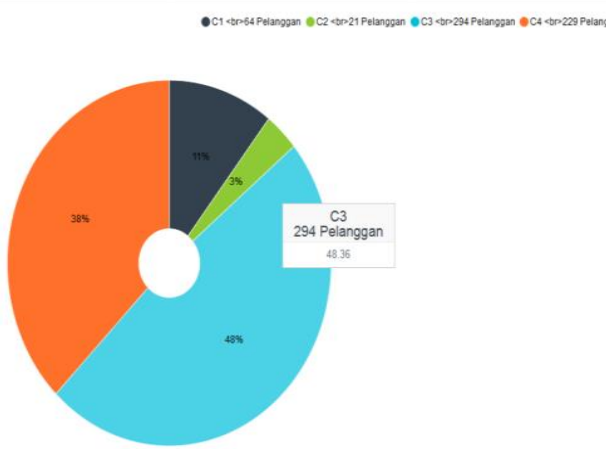

Sumber: (Jupriyanto. \& Nurlela, 2019)

Gambar 11. Jumlah Member Clustering Pelanggan

Jumlah member dalam masing-masing cluster di tampilkan dalam system / tool, sehingga tim marketing atau manajement syifamart bisa dengan mudah membuat terobosan-terobosan baru dengan existing cluster yang ada.

\begin{tabular}{|c|c|c|}
\hline & & PROFILE PELANGGAN \\
\hline 1 & 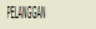 & 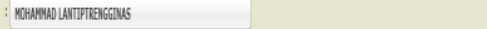 \\
\hline 2 & IBSS & 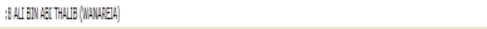 \\
\hline 1 & WTAP & 583313048 \\
\hline 4 & Custs: & $a$ \\
\hline I & NEEASER & Pengivs \\
\hline a & 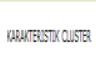 & 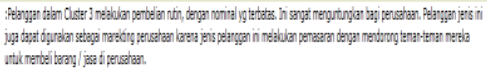 \\
\hline
\end{tabular}

Sumber: (Jupriyanto. \& Nurlela, 2019)

Gambar 12. Profile Pelanggan / Member 
Profile pelanggan di buat untuk memudahkan tim marketing atau manajemen Syifamart dalam memberikan service yang tepat kepada masing-masing pelanggan Syifamart.

\section{KESIMPULAN}

Proses data mining dari history transaksi penjualan 351,158 rows, kemudian dilakukan agregasi berdasarkan pelanggan menggunakan metode RFM. Setelah mendapatkan data RFM diekstraksi dengan menggunakan algoritma clustering k-means sehingga membentuk 4 (empat) cluster optimal. Keempat (empat) cluster tersebut kemudian diklasifikasikan dengan menggunakan algoritma decision tree untuk mengetahui setiap karakteristik pelanggan (customer profilling) sehingga perusahaan dapat mengetahui mana pelanggan potensial dan mana pelanggan yang tidak potensial.

Manajement syifamart bisa meprediksi kebutuhan persediaan akan produk, penelitian ini menggunakan metode tren dimana penjualan / stok di bulan selanjutnya bisa di prediksi dengan menggunkana history penjualan di bulan sebelumnya.

Untuk memfasilitasi perusahaan / manajement dalam mengambil keputusan hasil penelitian ini di implementasikan dengan cara membuat satu tool applikasi sehingga baik tim marketing dan pihak manajement bisa dengan mudah melihat hasil clustering dan bisa dengan mudah membuat rekomendasi model pemasaran yang terbaik berdasarkan dari hasil clustering dan profile pelanggan.

\section{REFERENSI}

Amborwati Armadyah, edi winarko. (2014). REVIEW PEMANFAATAN TEKNIK DATA MINING DALAM SEGMENTASI KONSUMEN. Prosiding Seminar Ilmiah Nasional Komputer Dan Sistem Intelijen (KOMMIT 2014), 8(Kommit), 66-73.

Hardiani, T., Hartanto, R., \& Mada, U. G. (2017). Segmentasi Nasabah Tabungan Menggunakan Model RFM ( Recency , Frequency , Monetary ) dan K-Means Pada Lembaga Keuangan Mikro, (May), 463-468.

Jupriyanto., \& Nurlela, S. (2019). Laporan Akhir Penelitian: Kerangka Pengambilan Keputusan Untuk Pemasaran Presisi Menggunakan Metode RFM, Algoritma K-Means Dan Decision Tree. Jakarta.

Maryani, I., \& Riana, D. (2017). Clustering and profiling of customers using RFM for customer relationship management recommendations. 2017 5th International Conference on Cyber and IT Service Management, 2-7. https://doi.org/10.1109/CITSM.2017.80892 58

Tsiptsis K, C., \& A. (2009). Data Mining Techniques in CRM.

Wardani, N. W., Dantes, G. R., Indrawan, G., Studi, P., Informasi, T., Studi, P., ... Pelanggan, S. (2018). Prediksi Customer Churn Dengan Algoritma Decision Tree C4 . 5. JURNAL RESISTOR, 1(1), 16-24.

widiarina. (2013). Algoritma Cluster Dinamik Untuk Optimasi Cluster Pada Algoritma KMeans Dalam Pemetaan Nasabah Potensial Algoritma Cluster Dinamik Untuk Optimasi Cluster Pada Algoritma K-Means Dalam. Prosiding SNATIF, 1(1), 33-36.

You, Z., Si, Y. W., Zhang, D., Zeng, X., Leung, S. C. H., \& Li, T. (2015). A decision-making framework for precision marketing. Expert Systems with Applications, 42(7), 3357-3367. https://doi.org/10.1016/j.eswa.2014.12.022 